\title{
Effects of Trichoderma and PGPR applications on growth and Verticillium wilt of eggplant
}

\author{
Melis BILGINTURAN@, Gursel HATAT KARACA® \\ Isparta University of Applied Sciences, Faculty of Agriculture, Plant Protection Department, 32260, Isparta \\ Corresponding author: G. Hatat Karaca, e-mail: gurselkaraca@isparta.edu.tr \\ Author(s) e-mail: meliskarapire@isparta.edu.tr
}

\section{ARTICLE INFO}

Received: March 16, 2021

Received in revised form: October 22, 2021

Accepted: October 26, 2021

\section{Keywords:}

Solanum melongena

Trichoderma spp.

PGPR

ISR

Enzyme activities

\begin{abstract}
In this study, effects of single and combined applications of biocontrol agents; Trichoderma spp. (T. atroviride, T. virens) and plant growth promoting rhizobacteria (Pseudomonas koreensis, Bacillus subtilis) on growth, wilt disease severity caused by Verticillium dahliae and plant defence-related enzymes (peroxidase, polyphenol oxidase, phenylalanine ammonium lyase and $\beta-1,3$ glucanase) of eggplant, were investigated. It was determined that single and combined applications of biological control agents reduced the severity of wilt disease caused by the pathogen, and $T$. atroviride isolate and its combinations with bacteria were the most effective applications. Biological control agents not only increased plant growth parameters in the experimental groups they were applied, but also the activities of defence-related peroxidase, polyphenol oxidase, phenylalanine ammonium lyase and $\beta-1,3$ glucanase enzymes in the plant samples taken from these groups. Inoculations with biocontrol agents especially increased stem diameter, length, fresh and dry weights and root lengths of the eggplants, compared to the pathogen inoculated ones. Although the enzyme activities of the plants changed depending on the period after the inoculations, mostly found to be higher on the plants inoculated with the pathogen and/or biocontrol agents, compared to the non-inoculated control plants.
\end{abstract}

\section{Introduction}

Eggplant (Solanum melongena L.) is one of the most important vegetable crops grown all over Turkey, except some parts of the Eastern Anatolia, Central Anatolia and Black Sea Regions. It is widely cultivated after tomatoes, peppers, cucumbers, watermelons and melons since the beginning of the 17 th century. According to FAO, Turkey produced a total of 822.659 tonnes of eggplant in about 23.337 hectares of land in 2019 (FAO 2021). Diseases are frequently encountered in eggplant cultivation and some important eggplant diseases caused by viruses (Sadeghi et al. 2008), bacteria (Yerchyk 2008) and fungi (Sholberg et al. 2007) were studied broadly. Common diseases caused by pathogenic fungi in eggplant cultivations are wilt, root rot, powdery mildew, white rot and gray mold, under field and greenhouse conditions (Altınok 2012). Verticillium dahliae Kleb. is a soil-borne fungal pathogen, which causes wilt disease and significantly decreases yield and quality in eggplant cultivation areas (Başay et al. 2011).

Vascular wilt diseases are among the most destructive plant pathogens and can destroy a crop in a whole cultivation area (Yadeta and Thomma 2013). Due to a large number of hosts of $V$. dahliae and the fact that it can survive in the soil for a long time, control strategies cannot be effective at the desired level. As a result of the side-effects of intensely used chemicals in agriculture on the environment and human health, biological control using beneficial microorganisms has gained importance, especially in the control of soil-borne diseases (Tjamos et al. 2004; Verma et al. 2019).

Trichoderma spp. and plant growth-promoting rhizobacteria (PGPR) known as biological control agents can protect plants against $V$. dahliae by colonizing the root system of plants by using mechanisms such as antibiosis against pathogens, competitive hyperparasitism-mycoparasitism and induced systemic resistance (ISR) (Tjamos et al. 2004).

In this study, the effects of single and combined treatments of Trichoderma species and PGPR against the severity of wilt disease caused by $V$. dahliae on eggplant, and on enzyme activities which has a role in plant defence, were investigated.

\section{Materials and Methods}

Eggplant variety 'Kemer' was raised from seed in the climate chamber for all treatments in this study. Pathogen $V$. dahliae and biocontrol agent isolates previously obtained from eggplant areas and kept in the Mycology Laboratory of the Plant Protection Department, Faculty of Agriculture, Isparta Applied Sciences University, were used in the study. Biocontrol agents were selected according to their compatible in vitro interactions and, Trichoderma isolates identified as T. virens and $T$. atroviride, and PGPR isolates identified as Pseudomonas koreensis and Bacillus subtilis by the MALDI-TOF method were used in this research. 
To determine in vivo effects of biological control agents on $V$. dahliae, a modification of the method from Akhtar and Azam (2014) was used. Eggplant seedlings with 3-4 true leaves were dipped for 15 minutes into spore suspensions of Trichoderma isolates at $1 \times 10^{8}$ spore $\mathrm{ml}^{-1}$ concentration prepared from 7 days old Potato Dextrose Agar (PDA; Merck) cultures, or suspensions with $1 \times 10^{8}-10^{10} \mathrm{cfu} \mathrm{ml}^{-1}$ concentration of bacteria grown in NA medium for $24-48$ hours. For combined applications, root tips of the seedlings were first trimmed with a sterile scissor and then seedlings were dipped into each suspension for 15 minutes. For pathogen inoculations, seedlings were additionally kept in the $V$. dahliae conidia suspension at $10^{6}$ spore $\mathrm{ml}^{-1}$ concentration for 15 minutes prepared from 7 days old PDA cultures. Positive controls were inoculated only with the pathogen and negative controls with sterile distilled water, by using the same method. Seedlings were then transferred to plastic pots with sterilized soil-peat-perlite-sand (2:1:1:1, v:v:v:v) mixture. The experiment was set up with 3 replications, with 5 plants per replication. Disease severity evaluations were made every week for 4 weeks by using a $0-4$ scale of Fahima and Henis (1995) and Townsend-Heuberger formula (Townsend and Heuberger 1943) was applied to the scale values to determine the severity rates (\%). Efficiencies of the treatments were also calculated by Abbott's formula (Abbott 1925). Plant growth parameters; stem diameter, stem and root lengths, fresh and dry weights were also determined.

To determine the effects of the biological control agents on the activities of enzymes related to plant defence, leaf samples of 2 grams were taken from eggplant seedlings in each application, one, seven and fourteen days after the inoculations. For use as crude enzyme extract in peroxidase, polyphenol oxidase and phenylalanine ammonium lyase analysis, 1 gram of leaf sample was homogenized with $0.1 \mathrm{M} 2 \mathrm{ml}$ phosphate buffer $\left(\mathrm{pH} 7.0,4^{\circ} \mathrm{C}\right)$. For the determination of $\beta-1,3$ glucanase activity, the remaining 1 gram sample was homogenized with $0.1 \mathrm{M}$ sodium citrate buffer $\left(\mathrm{pH} 5.0,4^{\circ} \mathrm{C}\right)$. After both homogenates were centrifuged at $10000 \mathrm{rpm}$ for 20 minutes, the resulting supernatants were removed (Saravanakumar et al. 2007).

Determination of peroxidase activity was carried out by the procedure using pyrogallol as a substrate. The mixture consisted of $0.32 \mathrm{ml}$ of $5 \%$ pyrogallol, $0.1 \mathrm{ml}$ of enzyme extract, $0.16 \mathrm{ml}$ of $0.5 \% \mathrm{H}_{2} \mathrm{O}_{2}, 0.32 \mathrm{ml}$ of $100 \mathrm{mM}$ potassium phosphate buffer (pH 6.0) and $2.1 \mathrm{ml}$ of purified water. The mixture was incubated for 10 minutes at $20 \pm 1^{\circ} \mathrm{C}$. After incubation, changes in absorbance at $420 \mathrm{~nm}$ wavelength has been observed for 3 minutes with 30-second intervals (Chance and Maehly 1955; Shannon et al. 1966).

Polyphenol oxidase enzyme analysis was performed using the method reported by Mayer et al. (1965). The reaction mixture contained $200 \mu \mathrm{l}$ enzyme extract and $1.5 \mathrm{ml} 0.1 \mathrm{M}$ sodium phosphate buffer ( $\mathrm{pH}: 6.5$ ). The reaction was initiated by adding $0.5 \mathrm{ml}$ of $0.01 \mathrm{M}$ catechol and the absorbance values at $420 \mathrm{~nm}$ wavelength were measured.

Phenylalanine ammonium lyase activity was determined according to McCallum and Walker (1990). The reaction mixture consisted of the following components; $1.2 \mathrm{ml}$ of 50 $\mathrm{mM}$ borate buffer ( $\mathrm{pH} 8.8$ ), $0.2 \mathrm{ml}$ of $20 \mathrm{mM}$ L-phenylalanine and $0.2 \mathrm{ml}$ of enzyme extract. After mixing $1.2 \mathrm{ml}$ of borate buffer and $0.2 \mathrm{ml}$ of L-phenylalanine for 5 minutes at $37^{\circ} \mathrm{C}$, the reaction was stopped by adding $0.2 \mathrm{ml}$ of enzyme extract and keeping it in a water bath at $37^{\circ} \mathrm{C}$ for 1 hour, and then mixing with $5 \mathrm{~N} 20 \mu \mathrm{HCl}$. Enzyme activity was measured at $290 \mathrm{~nm}$ wavelength using spectrophotometer.

$\beta-1,3$ glucanase enzyme activity was determined using the laminarin DNSA method of Pan et al (1991). Fort he analyses, $62.5 \mu \mathrm{l}$ of $4 \%$ laminarin and $62.5 \mu \mathrm{l}$ of enzyme extract were taken into tubes and incubated in water bath at $40^{\circ} \mathrm{C}$ for 10 minutes. The reaction was stopped by adding $375 \mu \mathrm{l}$ of dinitrosalicylic acid and boiling it for 5 minutes. The reaction mixture was completed to $5 \mathrm{ml}$ with distilled water, vortexed and absorbance was measured at $500 \mathrm{~nm}$ wavelength.

The data obtained in the study were subjected to analysis of variance using JMP statistical program (Ver.15.1.2) and differences among the means of the treatments were determined by the Tukey multiple comparison test $(P \leq 0.05)$.

\section{Results}

\subsection{Effects of biological control agents on wilt disease severity}

Effects of the separate or combined inoculations of eggplants with Trichoderma and PGPR isolates on disease severity rates caused by $V$. dahliae were shown in Table 1 . No symptom was observed on eggplant seedlings in the $1^{\text {st }}$ week, while wilt disease symptoms were seen in the second week and reached the maximum level in the third week. Disease severity rates decreased with the applications of biocontrol agents, especially with the application of $T$. atroviride alone or with bacteria. Although the decrease in disease severity rates was not statistically significant, the efficiency of $T$. atroviride inoculations were $75 \%$ in the second week and about $63 \%$ three and four weeks after inoculations.

\subsection{Evaluation of plant growth parameters}

Plants inoculated with $V$. dahliae and/or biological control agents were also evaluated in terms of growth parameters (Table 2). Pathogen inoculation decreased stem diameters, stem and root lengths and fresh and dry weights, compared to noninoculated control plants, while separate or combined inoculations of biocontrol agents increased all parameters. Inoculations of $P$. koreensis, $P$. koreensis $+T$. virens and $T$. atroviride $+B$. subtilis significantly increased stem diameters of eggplant seedlings when compared to the plants treated with pathogen solely. Separate and combined applications of Trichoderma and PGPR bacteria isolates significantly increased stem lengths of the seedlings and arranged in the same group with non-inoculated controls. T. atroviride, B. subtilis and combined inoculation of $T$. virens and $P$. koreensis inoculations also prevented the negative effect of the pathogen and significantly increased stem lengths of the plants inoculated with the pathogen. Although the biocontrol applications could not significantly increase stem fresh and dry weights of the plants when inoculated with the pathogen, some separate and combined inoculations of Trichoderma and PGPR stimulated plant growth and yielded higher values than non-inoculated control plants. All biocontrol applications except separate inoculations of $T$. virens and $P$. koreensis significantly increased root lengths of the seedlings inoculated with the pathogen. In terms of root fresh and dry weight parameters, all applications had increasing effect compared to the pathogen inoculated group, however this increase was not statistically significant. 
Table 1. Wilt disease severity on eggplant seedlings after inoculations of Verticillium dahliae (Vd) with separate and combined applications of biocontrol agents and efficiencies of the treatments

\begin{tabular}{|c|c|c|c|c|c|c|}
\hline \multirow[b]{2}{*}{ Treatments } & \multicolumn{2}{|c|}{ Day 14} & \multicolumn{2}{|c|}{ Day 21} & \multicolumn{2}{|c|}{ Day 28} \\
\hline & $\begin{array}{c}\text { Disease } \\
\text { severity }(\%)\end{array}$ & $\begin{array}{c}\text { Efficiency } \\
(\%)\end{array}$ & $\begin{array}{c}\text { Disease severity } \\
(\%)\end{array}$ & $\begin{array}{c}\text { Efficiency } \\
(\%)\end{array}$ & $\begin{array}{c}\text { Disease severity } \\
(\%)\end{array}$ & $\begin{array}{c}\text { Efficiency } \\
(\%)\end{array}$ \\
\hline $\mathrm{Vd}$ & $20.00 * \mathrm{a}^{* *}$ & - & $45.00 \mathrm{a}$ & - & $45.00 \mathrm{a}$ & - \\
\hline $\mathrm{Vd}+$ Trichoderma virens & $8.33 \mathrm{ab}$ & 58.35 & $23.33 \mathrm{a}$ & 48.15 & $23.33 \mathrm{a}$ & 48.15 \\
\hline $\mathrm{Vd}+T$. atroviride & $5.00 \mathrm{ab}$ & 75.00 & $16.66 \mathrm{ab}$ & 62.97 & $16.66 \mathrm{ab}$ & 62.97 \\
\hline $\mathrm{Vd}+$ Pseudomonas koreensis & $8.33 \mathrm{ab}$ & 58.35 & $16.66 \mathrm{ab}$ & 62.97 & $16.66 \mathrm{ab}$ & 62.97 \\
\hline $\mathrm{Vd}+$ Bacillus subtilis & $11.66 \mathrm{a}$ & 41.70 & $18.33 \mathrm{a}$ & 59.26 & $18.33 \mathrm{a}$ & 59.26 \\
\hline $\mathrm{Vd}+T$. virens $+P$. koreensis & $8.33 \mathrm{ab}$ & 58.35 & $26.66 \mathrm{a}$ & 40.75 & $26.66 \mathrm{a}$ & 40.75 \\
\hline $\mathrm{Vd}+T$. virens $+B$. subtilis & $10.00 \mathrm{ab}$ & 50.00 & $25.00 \mathrm{a}$ & 44.44 & $25.00 \mathrm{a}$ & 44.44 \\
\hline $\mathrm{Vd}+T$. atroviride $+P$. koreensis & $6.66 \mathrm{ab}$ & 66.70 & $16.66 \mathrm{ab}$ & 62.97 & $16.66 \mathrm{ab}$ & 62.97 \\
\hline $\mathrm{Vd}+T$. atroviride $+B$. subtilis & $5.00 \mathrm{ab}$ & 75.00 & $16.66 \mathrm{ab}$ & 62.97 & $16.66 \mathrm{ab}$ & 62.97 \\
\hline Control & $0.00 \mathrm{~b}$ & - & $0.00 \mathrm{~b}$ & - & $0.00 \mathrm{~b}$ & - \\
\hline
\end{tabular}

*: Disease severity rates were subjected to arc sin transformation before statistical analyses, but real values were given in the table. ${ }^{* *}:$ Means in the same column shown by the same letter are not statistically different from each other according to the Tukey test $(P \leq 0.05)$.

Table 2. Effects of biological control agents on growth parameters in plants inoculated with Verticillium dahliae (Vd)

\begin{tabular}{|c|c|c|c|c|c|c|c|}
\hline Treatments & $\mathrm{SD}(\mathrm{mm})^{*}$ & SL (cm) & SFW (g) & SDW (g) & $\mathrm{RL}(\mathrm{cm})$ & RFW (g) & RDW (g) \\
\hline Control & $3.268 \mathrm{ab}^{* *}$ & $21.900 \mathrm{a}$ & $4.836 \mathrm{ab}$ & $0.666 \mathrm{ab}$ & $11.393 \mathrm{ab}^{*}$ & $1.337 \mathrm{a}$ & $0.176 \mathrm{a}$ \\
\hline Trichoderma virens & $3.309 \mathrm{ab}$ & $22.820 \mathrm{a}$ & $5.440 \mathrm{ab}$ & $1.010 \mathrm{a}$ & $11.587 \mathrm{ab}$ & $1.445 \mathrm{a}$ & $0.221 \mathrm{a}$ \\
\hline T. atroviride & $3.383 \mathrm{ab}$ & $22.447 \mathrm{a}$ & $5.742 \mathrm{ab}$ & $0.965 \mathrm{a}$ & $11.900 \mathrm{ab}$ & $1.425 \mathrm{a}$ & $0.203 \mathrm{a}$ \\
\hline Pseudomonas koreensis & $3.495 \mathrm{a}$ & $23.073 \mathrm{a}$ & $6.287 \mathrm{ab}$ & $0.891 \mathrm{ab}$ & $12.153 \mathrm{ab}$ & $1.404 \mathrm{a}$ & $0.226 \mathrm{a}$ \\
\hline Bacillus subtilis & $3.417 \mathrm{ab}$ & $23.093 \mathrm{a}$ & $5.905 \mathrm{ab}$ & $0.878 \mathrm{ab}$ & $11.520 \mathrm{a}$ & $1.451 \mathrm{a}$ & $0.216 \mathrm{a}$ \\
\hline T. virens $+P$. koreensis & $3.721 \mathrm{a}$ & $24.160 \mathrm{a}$ & $6.461 \mathrm{ab}$ & $0.928 \mathrm{a}$ & $13.700 \mathrm{ab}$ & $1.618 \mathrm{a}$ & $0.202 \mathrm{a}$ \\
\hline T. virens + B. subtilis & $3.447 \mathrm{ab}$ & $22.907 \mathrm{a}$ & $5.297 \mathrm{ab}$ & $0.916 \mathrm{a}$ & $11.767 \mathrm{ab}$ & $1.464 \mathrm{a}$ & $0.236 \mathrm{a}$ \\
\hline T. atroviride $+P$. koreensis & $3.467 \mathrm{ab}$ & $23.320 \mathrm{a}$ & $5.691 \mathrm{ab}$ & $0.947 \mathrm{a}$ & $15.267 \mathrm{a}$ & $1.611 \mathrm{a}$ & $0.235 \mathrm{a}$ \\
\hline T. atroviride + B. subtilis & $3.479 \mathrm{a}$ & $22.827 \mathrm{a}$ & $7.633 \mathrm{a}$ & $0.867 \mathrm{ab}$ & $11.580 \mathrm{ab}$ & $1.518 \mathrm{a}$ & $0.211 \mathrm{a}$ \\
\hline $\mathrm{Vd}$ & $2.443 \mathrm{~b}$ & $15.320 \mathrm{~b}$ & $3.419 \mathrm{~b}$ & $0.444 \mathrm{~b}$ & $8.340 \mathrm{~b}$ & $1.126 \mathrm{a}$ & $0.124 \mathrm{a}$ \\
\hline $\mathrm{Vd}+T$. virens & $3.036 \mathrm{ab}$ & $18.833 \mathrm{ab}$ & $5.275 \mathrm{ab}$ & $0.866 \mathrm{ab}$ & $11.333 \mathrm{ab}$ & $1.388 \mathrm{a}$ & $0.194 \mathrm{a}$ \\
\hline $\mathrm{Vd}+T$. atroviride & $3.431 \mathrm{ab}$ & $21.767 \mathrm{a}$ & $5.487 \mathrm{ab}$ & $0.865 \mathrm{ab}$ & $13.600 \mathrm{a}$ & $1.421 \mathrm{a}$ & $0.177 \mathrm{a}$ \\
\hline $\mathrm{Vd}+$ P. koreensis & $2.961 \mathrm{ab}$ & $21.287 \mathrm{ab}$ & $5.085 \mathrm{ab}$ & $0.824 \mathrm{ab}$ & $12.500 \mathrm{ab}$ & $1.404 \mathrm{a}$ & $0.187 \mathrm{a}$ \\
\hline $\mathrm{Vd}+$ B. subtilis & $3.142 \mathrm{ab}$ & $22.413 \mathrm{a}$ & $5.242 \mathrm{ab}$ & $0.898 \mathrm{ab}$ & $12.567 \mathrm{a}$ & $1.381 \mathrm{a}$ & $0.202 \mathrm{a}$ \\
\hline $\mathrm{Vd}+T$. virens + P. koreensis & $3.308 \mathrm{ab}$ & $22.260 \mathrm{a}$ & $5.381 \mathrm{ab}$ & $0.884 \mathrm{ab}$ & $14.027 \mathrm{a}$ & $1.383 \mathrm{a}$ & $0.209 \mathrm{a}$ \\
\hline $\mathrm{Vd}+$ T. virens + B. subtilis & $3.085 \mathrm{ab}$ & $21.527 \mathrm{ab}$ & $5.453 \mathrm{ab}$ & $0.756 \mathrm{ab}$ & $13.887 \mathrm{a}$ & $1.430 \mathrm{a}$ & $0.206 \mathrm{a}$ \\
\hline $\mathrm{Vd}+T$. atroviride $+P$. koreensis & $3.257 \mathrm{ab}$ & $20.293 \mathrm{ab}$ & $5.131 \mathrm{ab}$ & $0.877 \mathrm{ab}$ & $13.807 \mathrm{a}$ & $1.417 \mathrm{a}$ & $0.206 \mathrm{a}$ \\
\hline $\mathrm{Vd}+T$. atroviride + B. subtilis & $2.999 \mathrm{ab}$ & $20.260 \mathrm{ab}$ & $5.357 \mathrm{ab}$ & $0.704 \mathrm{ab}$ & $13.727 \mathrm{a}$ & $1.411 \mathrm{a}$ & $0.199 \mathrm{a}$ \\
\hline
\end{tabular}

*: SD: Stem diameter, SL: Stem length, SFW: Stem fresh weight, SDW: Stem dry weight, RL: Root length, RFW: Root fresh weight, RDW: Root dry weight. **: Means in the same column shown by the same letter are not statistically different from each other according to the Tukey test $(P \leq 0.05)$.

\subsection{Enzyme activities of eggplants inoculated with $V$. dahliae and biocontrol agents}

Effects of the applications on defence-related enzyme activities of eggplant sedlings changed depending on the inoculated agents and time. However, almost all enzyme activities were higher in the plant samples inoculated with either pathogen and the biological agents than those in non-inoculated control plants. Peroxidase enzyme activity was found to be higher in the leaf samples taken one and seven days after inoculations of the plants with $T$. atroviride and the pathogen, while the highest enzyme activity value on the $14^{\text {th }}$ day was obtained with $P$. koreensis+pathogen treatment (Table 3). Polyphenol oxidase enzyme activity on the first day was found to be highest in the plant samples subjected to combined inoculations with $T$. atroviride and $P$. koreensis, while enzyme activity values in plants inoculated with $T$. virens $+P$. koreensis and $T$. atroviride+pathogen were statistically in the same group. On the $7^{\text {th }}$ day, the highest polyphenol oxidase activity was obtained by $T$. virens $+B$. subtilis combined treatment. Other
Trichoderma and bacteria combined applications were also statistically arranged in the same group. In the last analyses made with plant samples taken on the $14^{\text {th }}$ day after inoculations, $T$. atroviride $+B$. subtilis combined treatment yielded the highest enzyme value followed by $T$. virens $+B$. subtilis application (Table 4). The highest phenylalanine ammonium lyase activity on the $1^{\text {st }}$ day was obtained in $T$. virens $+P$. koreensis combined treatment. Activities of this enzyme were generally lower in combined inoculations of biocontrol agents and the pathogen on the first day, while these values increased in the subsequent measurements (Table 5). As in polyphenol oxidase activity, $T$. atroviride $+P$. koreensis combined inoculations yielded the highest $\beta-1,3$ glucanase activity on the first day, followed by other Trichoderma+bacterium combination. Results obtained on the $7^{\text {th }}$ day showed that single inoculation of $T$. virens resulted in the highest enzyme activity, and on the $14^{\text {th }}$ day, all applications were statistically similar in terms of $\beta-1,3$ glucanase activity (Table 6). 
Table 3. Effects of biological control agents on peroxidase activity (unit $\mathrm{ml}^{-1}$ ) in plants inoculated with Verticillium dahliae (Vd)

\begin{tabular}{|c|c|c|c|}
\hline Treatments & Day 1 & Day 7 & Day 14 \\
\hline Control & $2.672 \mathrm{~d}^{*}$ & $3.729 \mathrm{ab}$ & $3.463 \mathrm{~g}$ \\
\hline Trichoderma virens & $3.458 \mathrm{a}-\mathrm{d}$ & $4.268 \mathrm{ab}$ & $4.082 \mathrm{a}-\mathrm{d}$ \\
\hline T. atroviride & $3.440 \mathrm{a}-\mathrm{d}$ & $3.992 \mathrm{ab}$ & $3.768 \mathrm{c}-\mathrm{g}$ \\
\hline Pseudomonas koreensis & $3.184 \mathrm{~b}-\mathrm{d}$ & $4.081 \mathrm{ab}$ & $3.778 \mathrm{c}-\mathrm{g}$ \\
\hline Bacillus subtilis & $2.880 \mathrm{~cd}$ & $4.053 \mathrm{ab}$ & $3.530 \mathrm{fg}$ \\
\hline T. virens + P. koreensis & $4.046 \mathrm{ab}$ & $3.891 \mathrm{ab}$ & $3.623 \mathrm{~d}-\mathrm{g}$ \\
\hline T. virens + B. subtilis & $3.514 \mathrm{a}-\mathrm{d}$ & $3.748 \mathrm{ab}$ & $3.892 \mathrm{~b}-\mathrm{g}$ \\
\hline T. atroviride $+P$. koreensis & $3.858 \mathrm{a}-\mathrm{c}$ & $3.756 \mathrm{ab}$ & $3.539 \mathrm{fg}$ \\
\hline T. atroviride + B. subtilis & $2.993 \mathrm{~b}-\mathrm{d}$ & $3.704 \mathrm{~b}$ & $3.721 \mathrm{~d}-\mathrm{g}$ \\
\hline $\mathrm{Vd}$ & $3.857 \mathrm{a}-\mathrm{c}$ & $3.762 \mathrm{ab}$ & $3.581 \mathrm{e}-\mathrm{g}$ \\
\hline $\mathrm{Vd}+T$. virens & $4.351 \mathrm{a}$ & $4.212 \mathrm{ab}$ & $4.255 \mathrm{ab}$ \\
\hline $\mathrm{Vd}+T$. atroviride & $4.405 \mathrm{a}$ & $4.435 \mathrm{a}$ & $4.204 \mathrm{a}-\mathrm{c}$ \\
\hline $\mathrm{Vd}+P$. koreensis & $3.668 \mathrm{a}-\mathrm{d}$ & $4.317 \mathrm{ab}$ & $4.502 \mathrm{a}$ \\
\hline $\mathrm{Vd}+$ B. subtilis & $3.390 \mathrm{a}-\mathrm{d}$ & $3.757 \mathrm{ab}$ & $3.817 \mathrm{~b}-\mathrm{g}$ \\
\hline $\mathrm{Vd}+T$. virens $+P$. koreensis & $3.446 \mathrm{a}-\mathrm{d}$ & $3.912 \mathrm{ab}$ & $3.980 \mathrm{~b}-\mathrm{f}$ \\
\hline $\mathrm{Vd}+T$. virens $+B$. subtilis & $3.845 \mathrm{a}-\mathrm{c}$ & $3.665 \mathrm{~b}$ & $3.931 \mathrm{~b}-\mathrm{g}$ \\
\hline $\mathrm{Vd}+T$. atroviride $+P$. koreensis & $3.721 \mathrm{a}-\mathrm{d}$ & $4.387 \mathrm{ab}$ & $4.032 \mathrm{~b}-\mathrm{e}$ \\
\hline $\mathrm{Vd}+T$. atroviride $+B$. subtilis & 3.694 a-d & $4.113 \mathrm{ab}$ & $4.078 \mathrm{a}-\mathrm{d}$ \\
\hline
\end{tabular}

*: Means in the same column shown by the same letter are not statistically different from each other according to the Tukey test $(P \leq 0.05)$.

Table 4. Effects of biological control agents on polyphenol oxidase activity $\left(\mu \mathrm{g} \mathrm{ml}^{-1}\right)$ in plants inoculated with Verticillium dahliae (Vd)

\begin{tabular}{|c|c|c|c|}
\hline Treatments & Day 1 & Day 7 & Day 14 \\
\hline Control & $36.945 \mathrm{e}^{*}$ & $39.509 \mathrm{e}$ & $31.595 \mathrm{~d}$ \\
\hline Trichoderma virens & $39.167 \mathrm{de}$ & $48.415 \mathrm{~b}-\mathrm{e}$ & $38.826 \mathrm{~cd}$ \\
\hline T. atroviride & $41.458 \mathrm{c}-\mathrm{e}$ & $44.296 \mathrm{de}$ & $41.868 \mathrm{~b}-\mathrm{d}$ \\
\hline Pseudomonas koreensis & $53.680 \mathrm{a}-\mathrm{d}$ & $45.048 \mathrm{c}-\mathrm{e}$ & $51.834 \mathrm{a}-\mathrm{c}$ \\
\hline Bacillus subtilis & 46.740 a-e & $58.638 \mathrm{a}-\mathrm{c}$ & $38.774 \mathrm{~cd}$ \\
\hline T. virens $+P$. koreensis & $61.697 \mathrm{a}$ & $58.073 \mathrm{a}-\mathrm{c}$ & $43.167 \mathrm{~b}-\mathrm{d}$ \\
\hline T. virens + B. subtilis & $54.586 \mathrm{a}-\mathrm{d}$ & $62.313 \mathrm{a}$ & $57.424 \mathrm{ab}$ \\
\hline T. atroviride $+P$. koreensis & $62.108 \mathrm{a}$ & $54.193 \mathrm{a}-\mathrm{d}$ & $54.108 \mathrm{a}-\mathrm{c}$ \\
\hline T. atroviride + B. subtilis & $53.424 \mathrm{a}-\mathrm{d}$ & $53.834 \mathrm{a}-\mathrm{d}$ & $61.424 \mathrm{a}$ \\
\hline $\mathrm{Vd}$ & $44.364 \mathrm{~b}-\mathrm{e}$ & $43.321 \mathrm{de}$ & $38.159 \mathrm{~cd}$ \\
\hline $\mathrm{Vd}+$ T. virens & 47.185 a-e & $40.997 \mathrm{de}$ & $48.005 \mathrm{a}-\mathrm{c}$ \\
\hline $\mathrm{Vd}+T$. atroviride & $60.279 \mathrm{a}$ & $51.236 \mathrm{a}-\mathrm{e}$ & $53.014 \mathrm{a}-\mathrm{c}$ \\
\hline $\mathrm{Vd}+P$. koreensis & 50.979 a-e & $60.535 \mathrm{ab}$ & $54.022 \mathrm{abc}$ \\
\hline $\mathrm{Vd}+$ B. subtilis & $59.356 \mathrm{ab}$ & $53.031 \mathrm{a}-\mathrm{e}$ & $51.526 \mathrm{a}-\mathrm{c}$ \\
\hline $\mathrm{Vd}+T$. virens $+P$. koreensis & $56.296 \mathrm{a}-\mathrm{c}$ & $52.603 \mathrm{a}-\mathrm{e}$ & $52.261 \mathrm{a}-\mathrm{c}$ \\
\hline $\mathrm{Vd}+T$. virens + B. subtilis & $57.714 \mathrm{ab}$ & $48.552 \mathrm{~b}-\mathrm{e}$ & $52.808 \mathrm{a}-\mathrm{c}$ \\
\hline $\mathrm{Vd}+T$. atroviride $+P$. koreensis & $49.253 \mathrm{a}-\mathrm{e}$ & $58.672 \mathrm{a}-\mathrm{c}$ & $55.561 \mathrm{ab}$ \\
\hline $\mathrm{Vd}+T$. atroviride $+B$. subtilis & $53.304 \mathrm{a}-\mathrm{d}$ & $54.261 \mathrm{a}-\mathrm{d}$ & $52.056 \mathrm{a}-\mathrm{c}$ \\
\hline
\end{tabular}

*: Means in the same column shown by the same letter are not statistically different from each other according to the Tukey test $(P \leq 0.05)$.

\section{Discussion and Conclusion}

Considering the effects of Trichoderma and PGPR applications on the severity of wilt disease caused by $V$. dahliae, it was observed that the inoculations of biological control agents decreased wilt disease severity rates, although there was no statistically significant difference among the treatments. The lowest disease rate was obtained with the separate and combined treatments of $T$. atroviride with PGPR. In the previous studies on the effects of biological control agents against $V$. dahliae, it was also observed that single Trichoderma and PGPR treatments decreased disease severity rates, but the symptoms did not disappear completely and the application time of biological control agents also affected the disease severity (Amini 2017; Guenoun et al. 2018; Mokhtari et al. 2018; Zhang et al. 2018).
When the effects of the application of biological control agents together with the pathogen on plant growth parameters were examined, it was found that the combined treatments of Trichoderma and PGPR caused an increase in stem diameter, stem length, stem fresh and dry weights, root length, root fresh and dry weights of eggplants, compared to the treatments performed separately. It was previously reported that Trichoderma species (Mokhtari et al. 2018) and PGPR isolates (Guenoun et al. 2018) increased plant growth parameters in eggplant infected with $V$. dahliae.There are also reports on increased plant growth parameters as a result of the separate and combined treatments of Trichoderma and PGPR isolates on plants infected with different pathogens (Thilagavathi et al. 2007; Morsy et al. 2009; Chowdappa et al. 2013; Erper et al. 2013; Kumar et al. 2015). 
Table 5. Effects of biological control agents on phenylalanine ammonia-lyase activity ( $\left.\mu \mathrm{g} \mathrm{ml}^{1} \mathrm{~h}^{-1}\right)$ in plants inoculated with Verticillium dahliae (Vd)

\begin{tabular}{|c|c|c|c|}
\hline Treatments & Day 1 & Day 7 & Day 14 \\
\hline Control & $25.344 \mathrm{e}^{*}$ & $31.401 \mathrm{~d}$ & $26.956 \mathrm{~d}$ \\
\hline Trichoderma virens & $53.884 \mathrm{a}-\mathrm{d}$ & $57.392 \mathrm{a}-\mathrm{c}$ & $55.845 \mathrm{ab}$ \\
\hline T. atroviride & $53.841 \mathrm{a}-\mathrm{d}$ & $60.617 \mathrm{a}-\mathrm{c}$ & $42.577 \mathrm{bc}$ \\
\hline Pseudomonas koreensis & $63.950 \mathrm{ab}$ & $69.527 \mathrm{a}$ & $46.913 \mathrm{a}-\mathrm{c}$ \\
\hline Bacillus subtilis & $61.597 \mathrm{a}-\mathrm{c}$ & $56.477 \mathrm{a}-\mathrm{c}$ & $41.161 \mathrm{c}$ \\
\hline T. virens + P. koreensis & $70.203 \mathrm{a}$ & $55.017 \mathrm{a}-\mathrm{c}$ & $47.850 \mathrm{a}-\mathrm{c}$ \\
\hline T. virens + B. subtilis & $48.569 \mathrm{~b}-\mathrm{d}$ & $59.157 \mathrm{a}-\mathrm{c}$ & $49.723 \mathrm{a}-\mathrm{c}$ \\
\hline T. atroviride $+P$. koreensis & 53.492 a-d & 50.246 b-d & $38.111 \mathrm{~cd}$ \\
\hline T. atroviride + B. subtilis & 53.471 a-d & $44.669 \mathrm{~cd}$ & $43.972 \mathrm{bc}$ \\
\hline $\mathrm{Vd}$ & $64.168 \mathrm{ab}$ & $63.514 \mathrm{a}-\mathrm{c}$ & $58.481 \mathrm{a}$ \\
\hline $\mathrm{Vd}+T$. virens & $52.098 \mathrm{a}-\mathrm{d}$ & $54.865 \mathrm{a}-\mathrm{c}$ & $45.257 \mathrm{a}-\mathrm{c}$ \\
\hline $\mathrm{Vd}+T$. atroviride & $43.274 \mathrm{c}-\mathrm{e}$ & $51.532 \mathrm{a}-\mathrm{c}$ & $45.584 \mathrm{a}-\mathrm{c}$ \\
\hline $\mathrm{Vd}+P$. koreensis & $46.237 \mathrm{~b}-\mathrm{d}$ & $50.682 \mathrm{a}-\mathrm{c}$ & $44.277 \mathrm{bc}$ \\
\hline $\mathrm{Vd}+$ B. subtilis & $48.743 \mathrm{~b}-\mathrm{d}$ & $50.094 \mathrm{~b}-\mathrm{d}$ & $41.989 \mathrm{c}$ \\
\hline $\mathrm{Vd}+T$. virens $+P$. koreensis & $42.011 \mathrm{c}-\mathrm{e}$ & $50.747 \mathrm{a}-\mathrm{c}$ & $44.647 \mathrm{bc}$ \\
\hline $\mathrm{Vd}+T$. virens $+B$. subtilis & $43.231 \mathrm{c}-\mathrm{e}$ & $50.377 \mathrm{bc}$ & $41.793 \mathrm{c}$ \\
\hline $\mathrm{Vd}+T$. atroviride $+P$. koreensis & $47.828 \mathrm{~b}-\mathrm{d}$ & $65.279 \mathrm{ab}$ & $48.808 \mathrm{a}-\mathrm{c}$ \\
\hline $\mathrm{Vd}+T$. atroviride $+B$. subtilis & $40.246 \mathrm{de}$ & $51.924 \mathrm{a}-\mathrm{c}$ & $44.495 \mathrm{bc}$ \\
\hline
\end{tabular}

Table 6. Effects of biological control agents on $\beta$ - 1,3 glucanase activity $\left(\mu \mathrm{g} \mathrm{ml}^{-1}\right)$ in plants inoculated with Verticillium dahliae $(\mathrm{Vd})$

\begin{tabular}{|c|c|c|c|}
\hline Treatments & Day 1 & Day 7 & Day 14 \\
\hline Control & $353.5001^{*}$ & $336.530 \mathrm{~h}$ & $392.742 \mathrm{a}$ \\
\hline Trichoderma virens & $492.136 \mathrm{a}-\mathrm{c}$ & $553.955 \mathrm{a}$ & $439.106 \mathrm{a}$ \\
\hline T. atroviride & $462.742 \mathrm{c}-\mathrm{e}$ & $446.227 \mathrm{c}$ & $449.561 \mathrm{a}$ \\
\hline Pseudomonas koreensis & $433.197 \mathrm{e}-\mathrm{g}$ & $429.258 \mathrm{c}$ & $417.894 \mathrm{a}$ \\
\hline Bacillus subtilis & $402.136 \mathrm{gh}$ & 378.652 e-h & $400.167 \mathrm{a}$ \\
\hline T. virens $+P$. koreensis & 473.803 b-d & 420.470 c-e & $399.864 \mathrm{a}$ \\
\hline T. virens + B. subtilis & $503.955 \mathrm{ab}$ & $445.167 \mathrm{c}$ & $436.379 \mathrm{a}$ \\
\hline T. atroviride $+P$. koreensis & $520.773 \mathrm{a}$ & $341.227 \mathrm{~h}$ & $426.379 \mathrm{a}$ \\
\hline T. atroviride $+B$. subtilis & $401.682 \mathrm{gh}$ & $407.894 \mathrm{c}-\mathrm{f}$ & $438.500 \mathrm{a}$ \\
\hline $\mathrm{Vd}$ & $443.197 \mathrm{~d}-\mathrm{f}$ & $501.985 \mathrm{~b}$ & $458.348 \mathrm{a}$ \\
\hline $\mathrm{Vd}+T$. virens & $452.136 \mathrm{~d}-\mathrm{f}$ & $424.864 \mathrm{~cd}$ & $407.591 \mathrm{a}$ \\
\hline $\mathrm{Vd}+T$. atroviride & 362.7421 & $368.197 \mathrm{f}-\mathrm{h}$ & $415.167 \mathrm{a}$ \\
\hline $\mathrm{Vd}+P$. koreensis & $387.439 \mathrm{~h} 1$ & $350.924 \mathrm{gh}$ & $413.348 \mathrm{a}$ \\
\hline $\mathrm{Vd}+$ B. subtilis & $424.409 \mathrm{fg}$ & $404.864 \mathrm{c}-\mathrm{f}$ & $412.742 \mathrm{a}$ \\
\hline $\mathrm{Vd}+T$. virens $+P$. koreensis & $472.136 \mathrm{~b}-\mathrm{d}$ & $374.561 \mathrm{f}-\mathrm{h}$ & $426.985 \mathrm{a}$ \\
\hline $\mathrm{Vd}+T$. virens $+B$. subtilis & $373.045 \mathrm{~h} 1$ & $385.773 \mathrm{~d}-\mathrm{g}$ & $410.167 \mathrm{a}$ \\
\hline $\mathrm{Vd}+T$. atroviride $+P$. koreensis & $505.318 \mathrm{ab}$ & $422.288 \mathrm{~cd}$ & $413.500 \mathrm{a}$ \\
\hline $\mathrm{Vd}+T$. atroviride $+B$. subtilis & $386.227 \mathrm{~h} 1$ & $349.409 \mathrm{gh}$ & $411.682 \mathrm{a}$ \\
\hline
\end{tabular}

*: Means in the same column shown by the same letter are not statistically different from each other according to the Tukey test $(P \leq 0.05)$.

As a result of this study, it was found that Trichoderma and PGPR applications increased the activities of defence-related enzymes peroxidase, polyphenol oxidase, phenylalanine ammonium lyase and $\beta-1,3$ glucanase on eggplant seedlings inoculated with $V$. dahliae. These results showed that Trichoderma and PGPR isolates have the potential to stimulate enzymes involved in the defence mechanism of eggplant. Previous studies showed that Trichoderma spp., B. subtilis and Pseudomonas spp. treatments were responsible for the suppression of fungal diseases in plants due to the increase in peroxidase, polyphenol oxidase, phenylalanine ammonium lyase and $\beta-1,3$ glucanase activities (Ramamoorthy et al. 2007; Thilagavathi et al. 2007; Jayalakshmi et al. 2009; Latha et al. 2009; Houssien et al. 2010; Kumar et al. 2015; Chandrasekaran et al. 2017; $\mathrm{Li}$ et al. 2019). However, the sampling period, the types of biological control agents and their application times, plant variety and pathogenic microorganisms can affect the changes in enzyme activities.

The results obtained in this study showed that Trichoderma spp. and PGPR treatments reduced the disease severity of $V$. dahliae, had positive effects on plant growth and stimulated defence responses of the plant. An increase in peroxidase, polyphenol oxidase, phenylalanine ammonium lyase and $\beta-1,3$ glucanase enzyme activities of eggplant showed that the applications of Trichoderma species and PGPR promoted plant defence against the pathogen. The use of resistant varieties, solarization and fertilization are the main methods used in the disease management of $V$. dahliae. In addition, sustainable agriculture intends to increase and spread the use of biological control agents in the absence of effective chemical control, to control the disease or reduce its severity. 


\section{Acknowledgement}

This study is a part of the $\mathrm{PhD}$ thesis project (no: OYP05268-DR-14), supported by Isparta University of Applied Sciences, OYP Institutional Coordination Unit.

\section{References}

Abbott WS (1925) A method of computing the effectiveness of an insecticide. Journal of Economic Entomology 18: 265-267.

Akhtar MS, Azam T (2014) Effects of PGPR and antagonistic fungi on the growth, enzyme activity and Fusarium root-rot of pea. Archives of Phytopathology and Plant Protection 47: 138-148.

Altınok HH (2012) Antalya ve Mersin ili örtü altı patlıcan ekim alanlarında kurşuni küf ve beyaz çürüklük hastalıklarının yaygınlık oranlarının belirlenmesi. Bitki Koruma Büteni 52: 163-173.

Amini J (2017) Biocontrol of Verticillium wilt of potato caused by Verticillium dahliae using selected biocontrol agents. Applied Entomology and Phytopathology 84: 11-19.

Başay S, Seniz V, Tezcan H (2011) Reactions of selected eggplant cultivars and lines to Verticillium wilt caused by Verticillium dahliae Kleb. African Journal of Biotechnology 10: 3571-3573.

Chance B, Maehly AC (1955) Assay of Catalases and Peroxidases. Methods in Enzymology 2: 773-775.

Chandrasekaran M, Belachew ST, Yoon E, Chun SC (2017) Expression of $\beta$-1,3-glucanase (GLU) and phenylalanine ammonia-lyase (PAL) genes and their enzymes in tomato plants induced after treatment with Bacillus subtilis CBR05 against Xanthomonas campestris pv. vesicatoria. Journal of General Plant Pathology 83: 7-13.

Chowdappa P, Mohan Kumar SP, Lakshmi MJ, Upreti KK (2013) Growth stimulation and induction of systemic resistance in tomato against early and late blight by Bacillus subtilis OTPB1 or Trichoderma harzianum OTPB3. Biological Control 65: 109-117.

Erper I, Turkkan M, Atanasova L, Druzhinina IS, Karaca GH, CebIKilicoglu M (2013) Integrated assessment of the mycoparasitic and phytostimulating properties of Trichoderma strains against Rhizoctonia solani. Bulgarian Journal of Agricultural Science 19: 737-743.

Fahima T, Henis Y (1995) Quantitative assessment of the interaction between the antagonistic fungus Talaromyces flavus and the wilt pathogen Verticillium dahliae on eggplant roots. Plant and Soil 176: 129-137.

FAO (2021) Eggplant production. http://www.fao.org/faostat/en/\#data/QC. Accessed 10 January 2021.

Guenoun K, Chattaoui M, Bouri M, Naghmouchi K, Raies A (2018) Biological control of growth promoting rhizobacteria against verticillium wilt of pepper plant. Biologia, doi: 10.2478/s11756018-00169-9.

Houssien AA, Ahmed SM, Ismail AA (2010) Activation of tomato plant defense response against Fusarium wilt disease using Trichoderma harzianum and salicylic acid under greenhouse conditions. Research Journal of Agriculture and Biological Sciences 6: 328338.

Jayalakshmi SK, Raju S, Usha-Rani S, Benagi VI, Sreeramulu K (2009) Trichoderma harzianum $\mathrm{L} 1$ as apotential source for lytic enzmes and elicitor of defense responses in chickpea (Cicer arietinum L.) against wilt diseases caused by Fusarium oxysporum f. sp. ciceri. Australian Journal of Crop Science 3: 44-52.

Kumar SPM, Chowdappa P, Krishna V, Sandhya H (2015) Induction of defense-related proteins and growth promotion in tomato by mixture of Trichoderma harzianum OTPB3 and Bacillus subtilis OTPB1 and Pseudomonas putida OPf1 against Phytophthora infestans. African Journal of Microbiology Research 9: 96-110.

Latha P, Anand T, Ragupathi N, Prakasam V, Samiyappan R (2009) Antimicrobial activity of plant extracts and induction of systemic resistance in tomato plants by mixtures of PGPR strains and Zimmu leaf extract against Alternaria solani. Biological Control 50: 85-93.

Li M, Ma G, Lian H, Su X, Tian Y, Huang W, Mei J, Jiang X (2019) The effects of Trichoderma on preventing cucumber physiology. Journal of Integrative Agriculture 18: 607-617.

Mayer AM, Harel E, Shaul RB (1965) Assay of catechol oxidase, a critical comparison methods. Phytochemistry 5: 783-789.

McCallum JA, Walker JRL (1990) Phenolic biosynthesis during grain development in wheat: Changes in phenylalanine ammonia-lyase activity and soluble phenolic content. Journal of Cereal Science 11: 35-49.

Mokhtari W, Achouri M, Remah A, Boubaker H (2018) Verticillium dahliae-eggplant as the pathosystem model to reveal biocontrol potential of three Trichoderma spp. in greenhouse conditions. Atlas Journal of Biology 417-421.

Morsy EM, Abdel-Kawi KA, Khalil MNA (2009) Efficiency of Trichoderma viride and Bacillus subtilis as biocontrol agents gainst Fusarium solani on tomato plants. Egyptian Journal of Phytopathology 37: 47-57.

Pan SQ, Ye XS, Kuc J (1991) Association of $\beta-1,3$ glucanase activity and isoform pattern with systemic resistance to blue mold in tobacco induced by stem injection with Peronospora tabacina or leaf inoculation with tobacco mosaic virüs. Physiology and Moecular Plant Pathology 39: 25-39.

Ramamoorthy V, Raguchander T, Samiyappan R (2002) Induction of defence-related proteins in tomato roots treated with Pseudomonas fluorescence Pf1 and Fusarium oxysporum f. sp. lycopersici. Plant and Soil 239: 55- 68.

Sadeghi MS, Behjatnia SAA, Masumi M, Izadpanah K. (2008) Characterisation of a strain of potato virus $\mathrm{Y}$ causing eggplant mosaic in southern Iran. Australasian Plant Pathology 37: 79-86.

Saravanakumar D, Harish S, Loganathan M, Vivekananthan R, Rajendran L, Raguchander T, Samiyappan R (2007) Rhizobacterial bioformulation for the effective management of Macrophomina root rot in mungbean. Archives of Phytopathology and Plant Protection 40: 323-337.

Shannon LM, Kay E, Lew JY (1966) Peroxidase Isoenzymes from Horseradish Roots. I. Isolation and physical properties. Journal of Biological Chemistry 241: 2166-2172.

Sholberg PL, Walker MC, O'Gorman DT, Jesperson GD (2007) First report of Phytophthora capsici on cucurbitas and peppers in British Columbia. Canadian Journal of Plant Pathology 29: 153-158.

Thilagavathi R, Saravanakumar D, Ragupathi N, Samiyappan R (2007) A combination of bio-control agents improves the management of dry root rot (Macrophomina phaseolina) in green gram. Phytopathologia Mediterranea 46: 157-167.

Tjamos EC, Tsitsigiannis DI, Tjamos SE, Antoniou PP, Katinakis P (2004) Selection and screening of endorhizosphere bacteria from solarized soils as biocontrol agents against Verticillium dahliae of solanaceous hosts. European Journal of Plant Pathology 110: 35-44.

Townsend GR, Heuberger JW (1943) Methods for Estimating Losses Caused by Diseases in Fungicide Experiments. Plant Disease Report 27: 340-343.

Verma PP, Shelake RM, Das S, Sharma P, Kim J (2019) Plant growthpromoting rhizobacteria (PGPR) and Fungi (PGPF): Potential biological control agents of diseases and pests. In: Singh DP, Gupta VK, Prabha R (Eds), Microbial Inventions in Agriculture and Environment. Springer, pp. 281-312.

Yadeta KA, Thomma BPHJ (2013) The xylem as battleground for plant hosts and vascular wilt pathogens. Frontier in Plant Science 4: 97.

Yerchyk V (2008) Virulence of strains of Clavibacter michiganensis subsp. sepedonicus. Zemdirbyste 95: 359-365.

Zhang F, Li XL, Zhu SJ, Ojaghian MR, Zang JZ (2018) Biocontrol potential of Paenibacillus polymyxa against Verticillium dahliae infecting cotton plants. Biological Control 127: 70-77. 